\title{
INFLUENCE OF SOWING DATE ON DEVELOPMENT, HARVEST INDEX AND YIELD COMPONENTS FOR BREAD WHEAT CULTIVARS HAVING DIFFERENT THERMAL RESPONSES IN MIDDLE EGYPT \\ Moustafa, A. T. H. and S. A. El-Sawi. \\ Wheat Research Dept., Field Crop Res. Inst., A. R. C. Giza, Egypt.
}

\begin{abstract}
Two experiments were conducted in 2010/2011, 2011/2012 at Malawi Agric. Res. Sta., ARC to investigate the effect of sowing date according to the thermal time on developmental traits, yield and its component of four bread wheat cultivars (Triticum aestivum L) i.e. Giza168, Sids-1, Sids-12 and Shanwel-1 (Hexaploid) in three sowing dates i.e. $21^{\text {st }}$ November, $10^{\text {th }}$ December and $30^{\text {th }}$ December . The results showed that mean of all the sowing dates and cultivars arrived to anthesis at 88.6 DAS $\left(881.4^{\circ} \mathrm{C}\right)$ and to maturity 141.3 DAS $\left(1671.2^{\circ} \mathrm{C}\right)$ in season 1 , however they arrived to anthesis at 98.5 DAS $\left(973.0^{\circ} \mathrm{C}\right)$ and to maturity 152.6 DAS $\left(1986.5^{\circ} \mathrm{C}\right)$ in season 2. Heading date and anthesis were significantly affected by cultivars and sowing dates in both two growing seasons, also the interaction in the second season. Days to maturity were significantly affected by sowing date in two growing seasons and the interaction in the first season. Plant height was differed significantly by cultivars in two growing seasons and by sowing date and their interaction in the second season.

No. spikes $/ \mathrm{m}^{2}$ was significantly affected by sowing dates in both growing seasons and cultivars in the second season and their interaction in the first season. No. kernels/spike was significantly affected by cultivars, sowing dates and their interaction in the second season only. The weight of 1000 -kernels was significantly affected by sowing date in two growing seasons and by cultivars and their interaction in the second season only.

Grain filling period was significantly affected by sowing dates in two growing seasons and the interaction between cultivars $\times$ sowing date in the second season. Grain yield / plot $(\mathrm{kg})$ was significantly affected by cultivars and sowing dates in two growing seasons. Harvest index was significantly affected by cultivars in first season and by sowing date and their interaction in the second season. Mean H.I. of Sids 12 was slightly higher than other cultivars. Mean H.I. in sowing dates of optimum was higher than other dates in two growing seasons and their interaction in the second season.

Conclusions: The obtained results revealed that: 1 - The tested wheat genotypes were differed significantly among them in accordance to temperature and photoperiod requirements. 2- This study must be continuously arranged with all new released wheat genotypes for determining appropriate planting time for high yield.
\end{abstract}

Keywords:Sowing date, Thermal responses, Triticum aestivum, Harvest index $(\mathrm{HI})$, Grain filling period and yield.

\section{INTRODUCTION}

Wheat is the main cereal crop in the world, many factors limit yield in wheat (Triticum aestivum L), and the final yield is an outcome of the interaction of genetic, environmental conditions (for temperature and light) and agronomic factors. Variations in environment can be divided into two 
types, predictable and unpredictable. Perry and D'Antuono (1989) showed that in Australian cultivars biomass has increased when comparing modern to old cultivars but within the modern group recently released semi-dwarf cultivars were higher yielding only because of higher harvest index. Also the modern cultivars reached double ridge terminal spikelet anthesis and maturity earlier than the old cultivars but modern cultivars had a longer duration between double ridge and terminal spikelet stage (Siddique et al., 1989).

Grain yields were increased by early planting. A significant advantage of date 2 planting was recorded at Kemptville (lat. 45.00'). Kernel weight and test weight were reduced by late planting dates. Cultivars effects on grain yields were frequently significant, but were less on winter wheat survival (Andrews et al., 1992).

In general, Barley variety Tichedrett preferred intermediate planting while Barberousse and Acsad 176 performed well in late planting. Early planting resulted in good performance in sites where frost was not a problem (Bouzerzur and Refoufi, 1992). Gardener et al., (1993) reported that in southern USA. Spring type wheat cultivars are adapted to wider range of planting dates than winter type and recommended early planting of winter type wheat cultivars because of their vernalizatin requirement. Wheat late planting resulted in significant reduction in grain yield even though more spikes per square meter were produced; however reduced yield due to a decrease in kernel weigh and kernel number per spike, but the magnitude of yield loss was reduced by using an early-maturing cultivar (Shah et al., 1994).

Wheat is generally consider to enjoy an optimum temperature range of $17-23^{\circ} \mathrm{C}$ over the course of an entire growing season with a minimum temperature of $0^{\circ} \mathrm{C}$ and a maximum of $37^{\circ} \mathrm{C}$ beyond which growth stop (Porter and Gawith, 1999). Any fluctuation in temperature may reduce harvestable crop genetic potential (Pressey et al., 2007) by shortening the growth period resulting in lowered crop yield. Temperature more than optimum has great potential to accelerate developmental processes in wheat and further reduction in yield may occur due to increasing photorespiration in C3 species (Polley, 2002). Change in temperature has direct impacts on crop phenological seasonality in many ecological regions of the world (Chmielewski and Rotzer, 2002) so therefore understanding the relationship between temperature and phenological developmental process of crop plant is critical (Ye et al., 2002) because determination of production areas for introducing new species, information about climate change on phenological development is required.

More grain yield (optimum) was obtained from early planting wheat (optimum sowing date) generally compared with late planting (Donaldson et al., 2001) and Fodor and Palmai (2008) found that wheat produced less biomass with late sowing.

Hameed et al. (2003) concluded that days to emergence, tillers $/ \mathrm{m}^{2}$, days to heading and plant height were significantly affected by different planting dates, seed rates and $\mathrm{N}$ levels.

(Tammam and Tawfelis, 2004) observed that normal sowing gave higher grain yields than late sowing. Also, the results showed that all studied traits 
were significantly higher in the recommended sowing date compared to the late planting. Early sowing date produced the highest number of spikes $/ \mathrm{m}^{2}$, number of kernels/spike, 1000 kernels weight; biological yield and grain yield were significant in the recommended compared to the late dates planting. The analysis of variance showed high differences among cultivars for all studied traits. The interaction between sowing date and cultivars had significant effect for all studied traits.

Abdel-Nour, Nadya and Hayam (2011) reported that all studied traits (days to heading and maturity, plant height, number of spikes $/ \mathrm{m}^{2}$, number of kernels / spike, 1000-kernel weight, biological yield and grain yield ) were significantly the best in the recommended date compared to the late dates of planting. The analysis of variance showed high differences among cultivars for all studied traits. The interaction between sowing date and cultivars had significant effect for all studied traits.

Tawfelis et al. (2011) studied the performance of the twelve wheat genotypes and showed different responses to the different environments. The combined analysis of variance showed highly significant differences among planting dates and genotypes for all studied traits days to maturity, plant height, peduncle length, flag leaf area and straw yield (t/ha). Meanwhile genotypes $\times$ environments component mean squares were highly significant and significant for all studied characters except for peduncle length.

David Gouache et al. (2012) results showed that in the near future (2020-2049) a small to null increase in heat stress may occur. In the far future (2070-2099), the frequency of heat stress during grain filling should increase significantly. Adaptation through earlier sowing dates proves to be the least efficient. Use of earlier heading cultivars is somewhat efficient, and should be sufficient for the near future. Tolerance to heat stress appears to be the most promising adaptation strategy.

Zunfu Lv et al. (2013) studied many techniques including the downscaling of metrological data, rasterizing of sowing date parameterization of region cultivar and vectorization of soil data. This is an advance in flowering date in future climate compared to 2000s, but with a more homogeneous pattern for the whole producing China region. The changes in grain filling period are relatively stable.

Breeders are now seeking new sources of yield improvement and one pathway may be a continuation of past changes in morphological and physiological traits.

The present study was conducted to the effect of sowing dates (accumulated temperature) and bread wheat cultivars on development, $\mathrm{H}$. I. and yield components for determining the suitable date of planting for the new released varieties in Middle Egypt. 


\section{MATERIALS AND METHODS}

Two field experiments were conducted in two successive seasons 2010/2011 and 2011/2012 at Malawi Agric. Res. Sta., ARC, to study the effect of three sowing dates on development, H.I. and yield components of four bread wheat (Triticum aestivum L) namely, Giza-168, Sids-1, Sids-12 and Shandwel-1 treatments studied were: three sowing dates i.e. $21^{\text {th }}$ of November (recommended date), $10^{\text {th }}$ December (Mediocrity date) and $30^{\text {th }}$ December (Late date).

These treatments were arranged in split plot design with three replications. Sowing dates represented in the main-plot, while the four bread wheat were randomly distributed in the sub plots. Each plot consisted of 6 rows, $4 \mathrm{~m}$ long and $20 \mathrm{~cm}$ apart, plot size was $4.80 \mathrm{~m}^{2}$.

Table (1): Name, origin and pedigree of four bread wheat.

\begin{tabular}{|l|l|l|c|}
\hline No. & \multicolumn{1}{|c|}{ Parents } & \multicolumn{1}{|c|}{ Pedigree } & $\begin{array}{c}\text { Year of } \\
\text { release }\end{array}$ \\
\hline $\mathbf{1}$ & Giza-168 & MIL/BUC//SeriCM93046-8M-OY-0M-2Y-0B & 1987 \\
\hline $\mathbf{2}$ & Sids-1 & $\begin{array}{l}\text { HD2172/Pavon"S'//1158.57/Maya74"S"Sd46-4Sd- } \\
\text { 2Sd-1Sd-0Sd }\end{array}$ & 2007 \\
\hline $\mathbf{3}$ & Sids-12 & $\begin{array}{l}\text { BUC//7C/ALD/5/MAYA74/ON//1160-147/3/BB } \\
\text { GLL/4/HAT"S"/6/MAYA/VUL//CMH 74A.630/4*SX. } \\
\text { SD7096-4SD-1SD-1SD-OSD }\end{array}$ & 2007 \\
\hline $\mathbf{4}$ & Shandwel-1 & SITE//MO/4/NAC/TH.AC//38* PVN/3/MIRLO/BUC. & 2011 \\
\hline
\end{tabular}

\section{Studied characters:}

1-Development: heading, anthesis, maturity, grain filling period (DAS).

2-Plant height $(\mathrm{cm})$.

3-Yield components and harvest index (H.I.) where determined at harvest time.

Four rows $\left(3.2 \mathrm{~m}^{2}\right)$ were kept for grain yield determination; the relation of 10 plant characteristics to yield of grain also was computed.

The normal cultural practices of growing bread wheat in the region were followed.

Degree-days for time to emergence, heading stage, days to anthesis and days to maturity were calculated by summing daily degree-days (Tn), where daily degree-days were computed as:

$\mathrm{Tn}=[(\mathrm{T} \cdot \max +\mathrm{T} \cdot \min ) / 2]-\mathrm{Tb}$. Where T.max and T.min are the maximum and minimum daily air temperature, respectively and $T b$ is the base temperature $5^{\circ} \mathrm{C}$ bellow which no development occurs (Przuij and Mladenove 1999).

\section{RESULTS AND DISCUSSION}

\section{1-Phenology:}

Seasonal condition temperature for November-May growing season (Table 2,3 ) showed that days to $50 \%$ were emergency, heading, anthesis, 
maturity and the mean of temperature for some characters, and its overall seasons.

Full details of phonological development for each cultivar are presented in Siddique et al. (1989), and Karimi and Siddique (1991). Generally emergence, double ridge, heading, terminal spikelet, anthesis and physiological maturity.

The cultivars emerged together at 6.2 DAS $\left(71.0^{\circ} \mathrm{C}\right.$ days), was to heading stage 82.5 DAS $\left(813.7^{\circ} \mathrm{C}\right.$ days), and was to anthesis stage 88.6 DAS $\left(881.4^{\circ} \mathrm{C}\right.$ days) and was to maturity $141.3 \mathrm{DAS}\left(1671.2{ }^{\circ} \mathrm{C}\right.$ days) mean over all the first, season. Third sowing Shandwel- 1 cultivar reach heading stage at 80.0 DAS $\left(792.6^{\circ} \mathrm{C}\right.$ days) season 1 (Tables 2,3$)$ and the maturity stage was attained at 129.0 DAS $\left(1593.8^{\circ} \mathrm{C}\right.$ days) at the same season produced the lowest grain yield and biological yield. However the first sowing Sids-12 cultivar reached heading stage at about 80.3 DAS $\left(804.9^{\circ} \mathrm{C}\right.$ days) in season 1 and the maturity stage was attained at 147.7 DAS $\left(1691.0^{\circ} \mathrm{C}\right.$ days $)$ gave the production of successive grain yield and harvest index.

Third sowing Giza-168 cultivar reached heading stage at 88.3 DAS $\left(754.4^{\circ} \mathrm{C}\right.$ days) season 2 (Table 2,3 ) and the maturity stage was attained at 145.3 DAS $\left(2089.1^{\circ} \mathrm{C}\right.$ days) recorded the lowest grain yield and harvest index. Although first sowing, Giza-168 cultivar reached heading stage at 91.7 DAS $\left(844.7^{\circ} \mathrm{C}\right.$ days) season 2 and the maturity stage was attained at 159.7 DAS $\left(1913^{\circ} \mathrm{C}\right.$ days) gave the highest for harvest index.

\section{2- Heading stage:}

Growing seasons. Shandawel-1 was the latest cultivar in heading date compared with the other three cultivars with significant difference in both seasons. Heading was reached after 85.0 days by Shandwel- 1 in the first season which was later by 2.8, 2.6 and 4.7 days compared with Giza-168, Sids-1 and Sids-12, respectively, Similarly, in the second season Shandwel-1 reached heading later than Giza-168, Sids-1 and Sids-12 by 2.0, 2.9 and 3.2 days respectively.

It could be concluded that, Shandwel-1 was the latest cultivar in heading showing different genetically make up in this trait compared with the other studied cultivars. The obtained results were in agreement with those of ElSawi (1996), Tammam and Tawfelis (2004), Abdel-Nour, Nadya and Hayam (2011), David Gouach et al. (2012), and Zunfu Lv et al. (2013).

The results in (Table 3 ) showed that, sowing dates had significant effect on $50 \%$ heading in two seasons. Mean third sowing was the earliest in heading at 77.5 days, 88.5 days compared with first and second sowing in both two growing seasons.

Similar results were also reported by Hameed et al. (2003), Tammam and Tawfelis (2004), Abdel-Nour, Nadya and Hayam (2011), David Gouach et al. (2012), and Zunfu Lv et al. (2013).

The interaction between cultivars and sowing dates significantly influenced the heading date in second season only due to the thermal time. Similar results were also reported by Tammam and Tawfelis (2004), AbdelNour, Nadya and Hayam (2011). 
Moustafa, A. T. H. and S. A. El-Sawi.

T2-3 
3- Anthesis:

The results in (Table 3 ) showed that, wheat cultivars differed significantly in their anthesis in both of the two growing seasons. Sids-12 was the earliest cultivar in anthesis than the other three cultivars Giza-168, Sids-1 and Shandawel-1 in first and second seasons. On the other hand, Sids-1 was the latest cultivar in anthesis at first season however; Shandwel-1 was the latest cultivar in anthesis at second season. The results indicated significant differences between varieties and sowing dates in this trait for both seasons, but their interaction significantly affected this trait only in the second season due to the thermal time.

Similar results were also reported by Perry and D'Antuono (1989), Siddique et al. (1989), David Gouach et al. (2012), and Zunfu Lv et al. (2013).

Means of days to anthesis for third sowing date showed earliest anthesis date of 83.3 days at first season and 94.7 days for the second season compared with the first and second sowing dates in both seasons. Mean first sowing date showed latest in anthesis 101.4 days in the second growing season. This may by due to the higher temperatures at the third sowing date than those of the other sowing dates at the time of anthesis.

4- Maturity:

Results in (Table 3) showed that wheat cultivars were different in their maturity date in both two growing seasons and Sids-12 was the earliest cultivar in maturity earlier than Giza-168, Sids-1 and Shandwel-1 on the other hand no significant differences were detected between cultivars in both seasons.

Sids-1 was the latest cultivar in maturity at first season and Shandwel-1 at second season. The results reported by Perry and D'Antuono (1989), Shah, et al. (1994) El-Sawi (1996), Hameed et al. (2003), Abdel-Nour, Nadya and , Hayam (2011)), Tawfelis et al. (2011), and Zunfu Iv et al. (2013) showed that cultivars affected heading and maturity dates of wheat. The results in (Table 3 ) showed that sowing date significantly affected maturity date in two growing seasons. Mean first sowing time showed that latest in maturity 148.7 days in first season and 160.9 days in second season. Mean third sowing time was the earliest in maturity date 127.8 days at first season and 145.6 days at second season compared with the other studied sowing times. The conclusion is that developmental characters heading, anthesis and maturity dates were delayed 10-12 days in season two because thermal time response. The results in (Table 3 ) showed that, maturity date of wheat was significantly affected by the interaction between cultivars and sowing date in first season only due to the accumulated temperature similar results were reported by Hameed ...(2003) and Abdel-Nour, Nadya and, Hayam (2011). Also the results obtained by Perry and D'Antuono (1989), Shah et al. (1994), Hameed et al.(2003), Abdel-Nour, Nadya and , Hayam (2011), Tawfelis et al. (2011), David Gouach et al. (2012), and Zunfu Lv et al. (2013) showed that maturity date was affected by sowing date. 


\section{5- Grain filling period (days):}

The results in (Table 3) showed that, sowing date significantly affected grain filling period in both growing seasons. The mean first sowing date season 1 and 2 grain filling period 57.8 and 59.5 days age delayed grain filling time by $2.4,13.2$ days in season one and $7.7,8.6$ days in season two compared with second and third sowing date respectively. It could be concluded that, first sowing date combined delay grain filling period occurrence produced higher grain yield in season one and two. Similar results were obtained by David Gouache et al. (2012), and Zunfu Lv et al. (2013) who showed that grain filling period was affected by sowing date (thermal time and tropical also temperate areas). Table 3 shows that Sids-12 cultivar in season 1 and Shandwel-1 cultivar in season two were later in grain filling period, but they were superior in grain yield compared with the other cultivars under study in season one and two, on the other hand the results obtained by Simmons and Crookston (1979), Siddique et al. (1989), David Gouache et al. (2012), and Zunfu Lv et al. (2013) who showed that grain filling period was affected significantly by cultivars.

The results in (Table 3 ) showed also that interaction between cultivars $\times$ sowing dates significantly affected grain filling period in the second season due to the accumulated temperature. Similar results were reported by Pressey et al. (2007).

In general, the observed pattern of dry matter partitioning suggests that grain filling is source limited, particularly in plant sown in November (optimum).

\section{6-Plant height $(\mathrm{cm})$ :}

The four cultivars showed significant differences in plant height in both two growing seasons (Table 4). In both seasons Sids-1was the tallest cultivar and significantly surpassed Giza-168, Sids-12 and Shandwel-1 also Sids-12 was the shortest wheat cultivar in the two growing seasons. The present results indicated the genetically differences in the tested cultivars. Results reported by Bouzerzur and Refoufi (1992), El-Sawi (1996), Donaldson, et al. (2001), Hameed et al. (2003), Abdel-Nour, Nadya and , Hayam (2011) and Tawfelis et al. (2011) showed marked differences among the evaluated wheat cultivars grown in Egypt.

The effect of sowing dates on plant height was significant in the second season (Table 4). The mean of all the plant height in season 1 was $108.8 \mathrm{~cm}$ while in season 2 was $100.4 \mathrm{~cm}$. it is clear that a mean of two growing seasons late planting dates caused a reduction in plant height in the second and third planting date.

This could be due to that long plant duration gave a maximum vegetative growth when planting was carried out early. These results are in harmony with those obtained by Bouzerzur and Refoufi (1992), Donaldson et al. (2001), Hameed et al. (2003), Tawfelis, et al. (2011), and Abdel-Nour, Nadya and Hayam (2011).

The results in Table (4) showed that, plant height of wheat was significantly affected by the interaction between cultivars and sowing dates in second season only due to the thermal time. 
J. Plant Production, Mansoura Univ., Vol. 5 (2), February, 2014 T4 
Similar results were reported by Hameed et al.(2003) and Abdel-Nour, Nadya and Hayam (2011).

7- Spikes number/ $\mathbf{m}^{2}$ :

Results in (Table 4) showed that the four evaluated wheat cultivars differed significantly in number of spikes $/ \mathrm{m}^{2}$ in second season; the present result indicates that those cultivars are nearly similar in their tillering potentiality in first season. The genotype wheat Giza-168 produced higher number of spikes $/ \mathrm{m}^{2}$ than Sids-1, Sids-12 and Shandwel-1 in two growing seasons. The results were in agreement with those reported by Siddique, et al. (1989), Shah, et al. (1994), El-Sawi (1996), Tammam and Tawfelis (2004), Donaldson, et al. (2001), and Abdel-Nour, Nadya and Hayam (2011).

The results cleared also that this trait was significantly affected by sowing dates in both seasons which is in agreement with those obtained by Bouzerzur and Refoufi (1992), Shah, et al. (1994), Donaldson et al. (2001), Tammam and Tawfelis (2004), Abdel-Nour, Nadya and Hayam (2011), and Tawfelis et al. (2011), the interaction between cultivars and sowing dates in first season showed significant effect for this character due to the thermal time (Table 4).

\section{8- Number of kernels/spikes:}

The results in (Table 4) showed that number of kernels/spike showed significant differences among the tested cultivars, sowing dates and the interaction between cultivars $\times$ sowing date in the second season. In both two growing seasons Sids-12 cultivar produces greater number of kernels/spike compared with the other cultivars. The difference between Sids-12 and each of Giza-168, Sids-1 and Shandwel-1 in this character reached the level of significance in second season. Similar results were obtained by Siddique et al. (1989), Perry and D'Antuono (1989), El-Sawi (1996), Donaldson et al. (2001), Tammam and Tawfelis (2004), Abdel-Nour, Nadya and Hayam (2011), and Tawfelis et al. (2011).

The recommended sowing date produced higher number of kernels/spike compared with late sowing in the second swing in (Table 4). It seems that this character is greatly affected by the genetical make up of wheat cultivars and is not markedly influenced by environmental factors. The results obtained by Shah, et al. (1994), Donaldson et al. (2001), Tammam and Tawfelis (2004), and Abdel-Nour, Nadya and Hayam (2011) were similar to the present results. The interaction cultivar $x$ sowing date on number of kernels / spike was significant in second season only due to the accumulated temperature. These findings are in agreement with those obtained by Tammam and Tawfelis (2004), Abdel-Nour, Nadya and Hayam (2011).

\section{9- Thousand kernels weight:}

Results in (Table 4) showed that, the four cultivars varied significantly in 1000 kernels weight in second season only. Sids-1 recorded the greatest weight in two seasons and significantly surpassed Giza-168, Sids-12 and Shandwel-1 in second season. On the other hand, Giza-168, recorded the lowest kernel index which was lower than Sids-1, Sids-12 and Shandwel-1. It could be concluded that Sids-1 was superior in kernel index and Giza-168, was inferior one, whereas, Sids-12 and Shandwel-1 were in between. Similar results were also obtained by Andrews, et al. (1992), Shah, et al. (1994), El- 
Sawi (1996), Donaldson, et al. (2001), Tammam and Tawfelis et al. (2004), and Abdel-Nour, Nadya and Hayam (2011).

Results in Table (4) showed that plots sown at optimum ( $21^{\text {st }}$ November) produced heavier kernel than late sown $\left(30^{\text {th }}\right.$ December). Thousand kernels weight was found to be decreased proportionally as the planting was delayed. Meanwhile, at the optimum planting, the plants had suitable and longer thermal time (accumulated temperature) for vegetative growth, which resulted in the active photosynthesis and maximum translocation of the assimilates to the kernel and thus had heavier kernels, Andrews et al. (1992), Shah, et al. (1994), El-Sawi (1996), Donaldson et al. (2001), Hameed et al. (2003), Tammam and Tawfelis (2004), and Abdel-Nour, Nadya and Hayam (2011) reported that early sowing compared with late sowing produced maximum grain weight and grain yield.

The effect of the interaction between cultivars and sowing dates treatments was significant on thousand kernels weight in second season only due to the accumulated temperature. These findings are in agreement with those obtained by Hameed et al. (2003) and Abdel-Nour, Nadya and Hayam (2011).

\section{0- Grain yield/plot $(\mathbf{k g})$ :}

The analysis for grain yield $\mathrm{kg} / \mathrm{plot}$ (Table 4) showed that sowing date and cultivars had significant effect in both growing seasons.

The evaluated wheat cultivars differed in grain yield $\mathrm{kg} / \mathrm{plot}$ in the growing seasons. The average of grain yield showed that the cultivar Sids-12 and Shandwel-1 gave a higher grain yield in the first and second seasons, respectively. The results indicate differences among cultivars in their productivity as confirmed by many investigators i.e. Andrews et al. (1992), Bouzerzur and Refoufi (1992), Gardener et al. (1993), Shah et al. (1994), ElSawi (1996), Donaldson et al. (2001), Hameed et al. (2003), Tammam and Tawfelis (2004), and Abdel-Nour, Nadya and Hayam (2011).

Results in (Table 4) showed that planting date treatments affected grain yield/plot $(\mathrm{kg})$ in both seasons, where the mean of the first season sowing date $1704.2{ }^{\circ} \mathrm{C}$ days thermal time in season one at days to maturity, 1940.2 ${ }^{\circ} \mathrm{C}$ days thermal time in season two at days to maturity gave high grain yield in (Table 4). Although the mean third sowing date $1561.8{ }^{\circ} \mathrm{C}$ thermal time in season 1 at days to maturity, $2100.2{ }^{\circ} \mathrm{C}$ thermal time in season 2 at days to maturity clearly lagged behind it. The mean grain yield reduction due to the third sowing ranged from $0.93 \mathrm{~kg} /$ plot in season 1 to $1.13 \mathrm{~kg} / \mathrm{plot}$ in season 2 (Table 4) comparing with the first sowing date .

Delaying the sowing date decreased grain yield (though more spikes $/ \mathrm{m}^{2}$, however reduced in kernel weight and kernel number/spike; furthermore analysis of data revealed that sowing at optimum time favored the maximum partitioning of photosynthesis when compared to the late sowing and gave maximum grain yield (Table 4). Also, there was sufficient time available for plant growth and development at early sowing. The results indicate differences among cultivars in their productivity as confirmed by many investigators i.e. Andrews et al. (1992), Bouzerzur and Refoufi (1992), 
Gardener et al. (1993), Shah et al. (1994), Donaldson et al. (2001), Hameed et al. (2003), Tammam and Tawfelis (2004), Abdel-Nour, Nadya and Hayam (2011), and Zunfu Lv et al. (2013). The interaction cultivars $\times$ sowing dates on grain yield was not significant in both growing seasons (Table 4).

Figure $1(a \& b)$ shows the effect of sowing date of four wheat verities on grain yield (kg/plot) over two seasons and their defects. It is indicated that the highest production of grain yield was attained by Sids-12 flowed by Shandwel-1 and the lowest deficit was resulted from Giza-168 over two season that may be due to the high stability of this variety.

\section{1- Harvest index:}

The results showed that the four evaluated cultivars were significantly differed in harvest index in the first season. Sids-12 showed significant in first season and a slight increase in the second season in H.I. compared with Giza168, Sids-1 and Shandwel-1, but the increase was below the significance level. The results of H.I. followed the same pattern as those of both biological and grain yield in two growing seasons.

Concerning the effect of sowing dates on H.I. in (Table 4) showed a significant effect in the second season and the greatest H.I. was recorded at first sowing (39.5\%) whereas the lowest H.I. (35.2\%) was obtained at the third sowing.

The results reported by Perry and D'Antuono (1989), Siddique et al. (1989), Donaldson et al. (2001), Wajid et al. (2004), and Fodor and Palmai (2008) indicated significant effect of cultivars and sowing dates on H.I.

Conclusion, all cultivars constantly produced less straw as sowing date was delayed and H.I was consistently low with the tall cultivars Buchanan also grain yield was always the highest for the semidwarf Eltan cultivar (Donaldson et al. 2001).

The results in (Table 4) showed that interaction cultivars $\times$ sowing dates significantly affected $\mathrm{H}$.I in the second season due to monthly meteorological data. Similar results were reported by Pressey et al. (2007) and Fodor and Palmai (2008). 
J. Plant Production, Mansoura Univ., Vol. 5 (2), February, 2014

F 1 


\section{REFERENCES}

Abdel Nour, Nadya, A. R., and Hayam, S. A. (2011). Influence of sowing date and nitrogen fertilization on yield and its components in some bread wheat genotypes. Egypt J. Agric. Res., 89(4):1413-1432.

Andrews, C. J.; Pomeroy, M. K.; Seaman, W. L., and Hoekstro. (1992). Planting dates and seeding rates for soft white winter wheat in Eastern Ontario. Can. J. PI. Sci. 72: 391-402.

Bouzerzur and Refoufi B. (1992). Effect of sowing date and rate, and sit environment on the performance of Barley cultivars grown in the Algerian high plateaux Rachis 11: (1/2):19-24.

Chmielewski, F. M., and Rotzer, T. (2002). Annual and variability of the beginning of growing season in Europe in relation to air temperature changes. Climate Res., 19: 257-264.

David Gouache; Xavier Le Bris; Matthieu Bogard; Olivier Deudon; Christian Page, and Phlippe Gate. (2012). Evaluating agronomic adaptation options to increasing heat stress under climate change during wheat grain filling in France. Europ. J. Agron., 39:62-70.

Donaldson, E.; Schillinger, W. F., and Dofing, S. M. (2001). Straw production and grain yield relationships in winter wheat. Crop Sci., 41: 100-106.

El-Sawi, S. A. M. (1996). Evaluation of different wheat genotypes in relation to growth physiological characters and their contribution to grain yield. M. Sc. Thesis . Fac. Agric. Moshtohor, Zagazig Univ., Egypt.

Fodor, L., and O. Palmai. (2008). The influence of nitrogen fertilization and sowing date on wheat lines of winter wheat. Cereal Res. Commun., 36: 1159-1162.

Gardener, F.P.; Barnet, R. D.; Soffes, A. R., and Johnson, J. W. (1993). Reproductive development of eight wheat cultivars and a triticale as influenced by sowing date. Crop Sci. 33: 118-123.

Hameed, E.; Wajid, A. S.; Shad, A. A.; Jehan, B., and Tilah, M. (2003). Effect of different planting dates, seed rate and nitrogen levels on wheat. Asian J. PI. Sci., 2 (6): 467-474.

Karimi, M. M., and Siddique, K. H. M. (1991). Crop growth rates of old and modern wheat cultivars. Aust. J. Agric. Res., 42: 13-20.

Perry, M. W., and D'Antuono, M. F. (1989). Yield improvement and associated characteristics of some Australian spring wheat introduced between 1960 and 1982. Aust. J. Agric. Res., 40: 457-472.

Polley, H. W. (2002). Implications of atmospheric and climate change for crop yield. Crop Sci., 42: 131-140.

Porter, J. R., and Gawith, M. (1999). Temperature and the growth and development of wheat: a review. Europ. J. Agron., 10: 23-36.

Pressey, R. L.; Cabeza, M.; Watts, M. E.; Cowling, R. M., and Wilson, K. A. (2007). Conservation planting in a changing world. Trends Ecol. Evol., 22: 583-592.

Przuij, N., and Mladenove, N. (1999). Inheritance of grain filling duration in spring wheat. Plant breeding 118: 517-521. 
Shah, S. A.; Harrison, D. J.; Boquet, P. D. Colyer, and Moore, S. H. (1994). management effects on yield components of late planted wheat. Crop Sci. 34: 1298-1303.

Siddique, K. H. M.; Belford, R. K.; Perry, M. W., and Tennant, D. (1989). Growth, development and light interception of old and modern wheat cultivars in a Mediterranean type environment Aust. J. Agric. Res. 40: 473-487.

Simmons. S. R. , and R. K. Crookston (1979). Rate and duration of growth of kernels formed at specific flowerets in spikelets of spring wheat Crop Sci., 19:690-693.

Tammam, A. M., and Tawfelis, M. B. (2004). Effect of sowing date and nitrogen fertilizer levels in relation to yield and yield components of durum wheat (Triticum turgidum var, durum) under upper Egypt environments. J. Agric. Sci. Mansoura Univ., 29 (10): 5431-5442.

Tawfelis, M. B.; Khieralla, K. A. A.; El Morshidy, M. A., and Feltaous, Y. M. (2011). Genetic diversity for heat tolerance in some bread wheat genotypes under Upper Egypt conditions. Egypt. J. Agric. Res., 89 (4):1463-1479.

Wajid, A., A.; Hussain, A. A.; Goheer, A. R.; Ibrahim, M., and Mussaddique, M. (2004). Effect of sowing date and plant population on biomass, grain yield and yield components of wheat. Int. J. Agric. Biol., 6: 1003-1005.

Ye, D. Z.; Fu, C. B., and Dong, W. J. (2002). Progress and future of global change science. Adv. Earth Sci., 17: 467-469.

Zunfu Lv; Xiaojun liu; Weixing Cao, and Yan Zhu (2013). Climate change impacts on regional winter wheat production in main wheat production regions of China. Agriculture and Forest Metreology 171-172:234-248.

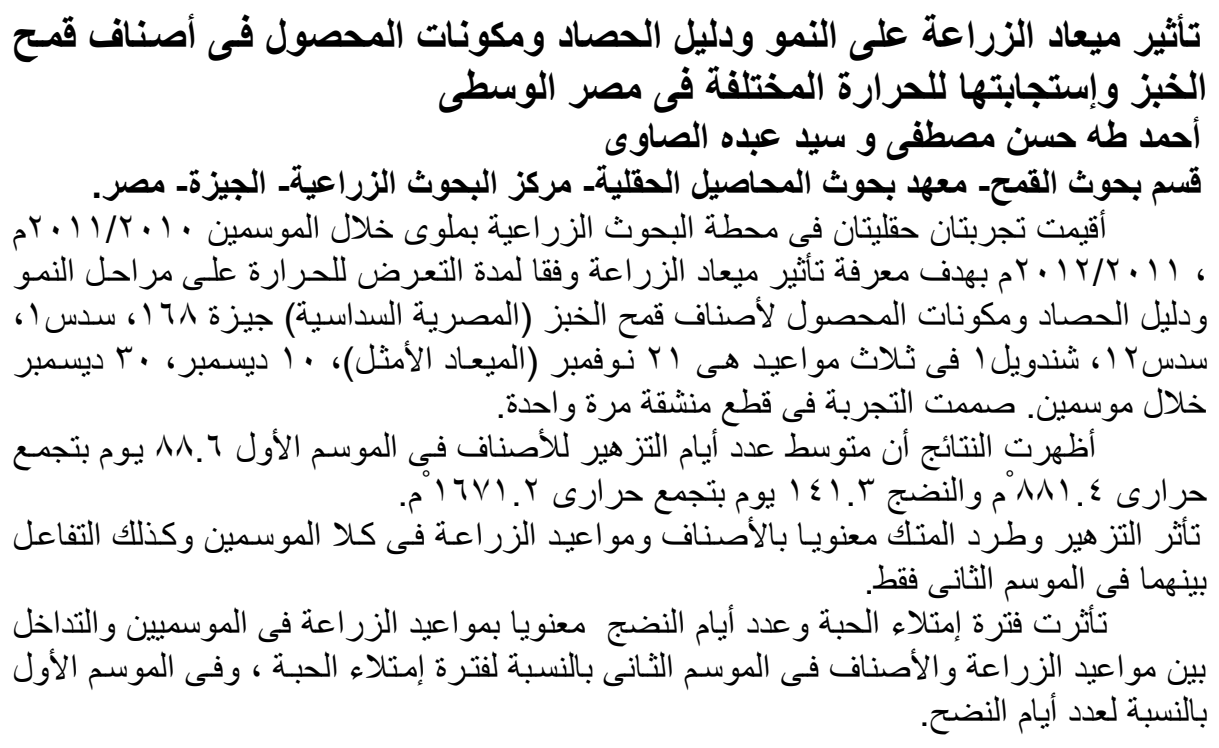


Moustafa, A. T. H. and S. A. El-Sawi.

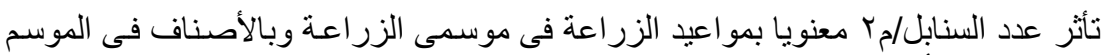

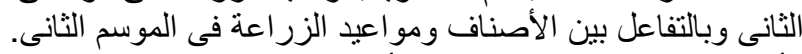

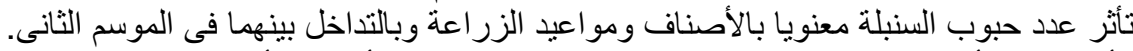

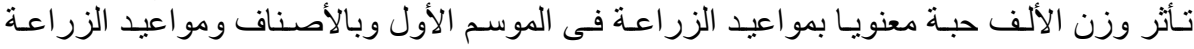
وبالتداخل بينهما في الموسم الثانى.

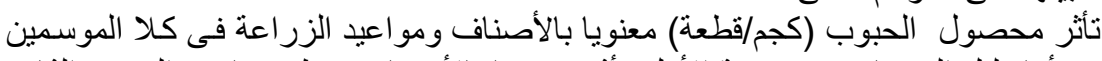

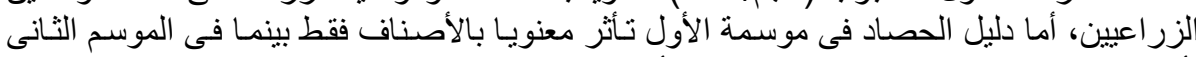

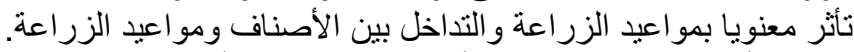

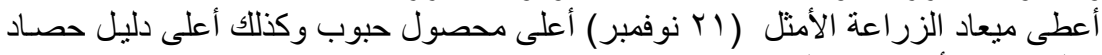
بالمقارنة بالمو اعيد الأخرى فى الموسمين.

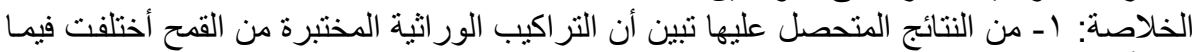

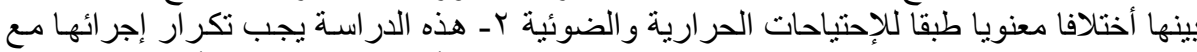

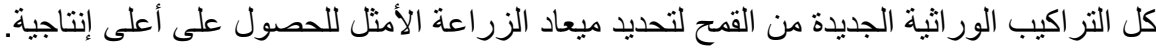

كلية الزراعة - جامعة المنصورة مركز البحوث الزراعية
قام بتحكيم البحث

أ. أد / محمود سليمان سلطان البحل

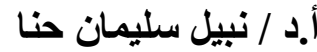



Table (2):Thermal time ( ${ }^{\circ} \mathrm{C}$ days) for the emergence stag, heading, anthesis, maturity and grain filling period for cultivars and sowing dates.

\begin{tabular}{|c|c|c|c|c|c|c|c|c|c|c|c|c|c|c|c|c|c|c|c|c|c|}
\hline & \multirow{3}{*}{$\begin{array}{l}\text { Varieti } \\
\text { es. } \\
\text { (A) }\end{array}$} & \multirow{2}{*}{\multicolumn{4}{|c|}{ Days to emergence stage }} & \multicolumn{4}{|c|}{ Days to heading sta } & \multicolumn{4}{|c|}{ sis stag } & \multicolumn{4}{|l|}{ Day } & \multicolumn{4}{|c|}{ Grain filling period } \\
\hline & & \multicolumn{2}{|c|}{ Sowing dates (B) } & & \multirow{2}{*}{$\begin{array}{l}\mathrm{Me} \\
\text { an } \\
\text { (A) } \\
\end{array}$} & \multicolumn{3}{|c|}{ Sowing dates (B) } & \multirow{2}{*}{$\begin{array}{l}\text { Mea } \\
n \\
\text { (A) }\end{array}$} & \multicolumn{3}{|c|}{ Sowing dates (B) } & \multirow{2}{*}{$\begin{array}{l}\text { Mea } \\
n \\
\text { (A) }\end{array}$} & \multicolumn{3}{|c|}{ Sowing dates (B) } & \multirow{2}{*}{$\begin{array}{l}\text { Mean } \\
\text { (A) }\end{array}$} & \multicolumn{3}{|c|}{ Sowing dates (B) } & \multirow{2}{*}{$\begin{array}{l}\text { Mean } \\
\text { (A) }\end{array}$} \\
\hline & & First & $\begin{array}{l}\text { Sec } \\
\text { ond }\end{array}$ & $\begin{array}{l}\text { Thir } \\
d\end{array}$ & & First & $\begin{array}{l}\text { Sec } \\
\text { ond }\end{array}$ & $\begin{array}{l}\text { Thir } \\
d\end{array}$ & & First & $\begin{array}{l}\text { Sec } \\
\text { ond }\end{array}$ & Third & & First & $\begin{array}{l}\text { Seco } \\
\text { nd }\end{array}$ & Third & & First & $\begin{array}{l}\text { Sec } \\
\text { ond }\end{array}$ & Third & \\
\hline \multirow{6}{*}{ 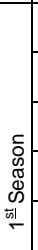 } & $\begin{array}{l}\text { Giza- } \\
168\end{array}$ & $\begin{array}{l}\begin{array}{l}64.4 \\
{ }^{\circ} \mathrm{C}\end{array} \\
\end{array}$ & $\begin{array}{l}79.1 \\
{ }^{\circ} \mathrm{C}\end{array}$ & $\begin{array}{l}35 . \\
3^{\circ} \mathrm{C}\end{array}$ & $\begin{array}{l}59 . \\
6^{\circ} \mathrm{C}\end{array}$ & $\begin{array}{l}785 . \\
3^{\circ} \mathrm{c}\end{array}$ & $\begin{array}{l}873 . \\
3^{\circ} \mathrm{C}\end{array}$ & $\begin{array}{l}755 . \\
4^{\circ} \mathrm{C}\end{array}$ & $\begin{array}{l}804 . \\
3^{\circ} \mathrm{c}\end{array}$ & $\begin{array}{l}908 . \\
1{ }^{\circ} \mathrm{C}\end{array}$ & $\begin{array}{l}894 . \\
3^{\circ} \mathrm{c}\end{array}$ & $\begin{array}{l}822.8 \\
{ }^{\circ} \mathrm{C}\end{array}$ & $\begin{array}{l}875 . \\
1^{\circ} \mathrm{C}\end{array}$ & $\begin{array}{l}1707 . \\
7^{\circ} \mathrm{C}\end{array}$ & $\begin{array}{l}1767 . \\
6^{\circ} \mathrm{c}\end{array}$ & 1520. & 1665. & $\begin{array}{l}799.6 \\
{ }^{\circ} \mathrm{C}\end{array}$ & $\begin{array}{l}873 . \\
3^{\circ} \mathrm{C}\end{array}$ & $\begin{array}{l}697.7 \\
{ }^{\circ} \mathrm{C}\end{array}$ & 790.2 \\
\hline & $\begin{array}{l}\text { Sids- } 1 \\
\end{array}$ & $\begin{array}{l}64.4 \\
{ }^{\circ} \mathrm{C}\end{array}$ & $\begin{array}{l}60.2 \\
{ }^{\circ}{ }^{\circ} \mathrm{C}\end{array}$ & $\begin{array}{l}62 . \\
1^{\circ} \mathrm{C}\end{array}$ & $\begin{array}{l}62 . \\
2^{\circ} \mathrm{C}\end{array}$ & $\begin{array}{l}804 . \\
3^{\circ} \mathrm{C}\end{array}$ & $\begin{array}{l}844 . \\
5^{\circ} \mathrm{C}\end{array}$ & $\begin{array}{l}765 . \\
8^{\circ} \mathrm{C}\end{array}$ & $\begin{array}{l}804 . \\
9^{\circ} \mathrm{C}\end{array}$ & $\begin{array}{l}929 . \\
6^{\circ} \mathrm{C}\end{array}$ & $\begin{array}{l}901 . \\
1^{\circ} \mathrm{C}\end{array}$ & $\begin{array}{l}861.8 \\
{ }^{\circ} \mathrm{C}\end{array}$ & $\begin{array}{l}897 . \\
5^{\circ} \mathrm{C}\end{array}$ & $\begin{array}{l}1727 . \\
2^{\circ} \mathrm{C}\end{array}$ & $\begin{array}{l}1767 . \\
6^{\circ} \mathrm{C}\end{array}$ & $\begin{array}{l}1612 . \\
4^{\circ} \mathrm{C}\end{array}$ & $\begin{array}{l}1702 . \\
4^{\circ} \mathrm{C}\end{array}$ & $\begin{array}{l}797.6 \\
{ }^{\circ} \mathrm{C}\end{array}$ & $\begin{array}{l}866 . \\
5^{\circ} \mathrm{C}\end{array}$ & 750.6 & 804.9 \\
\hline & Sids- & 90.3 & 79.1 & 69. & 79. & 804. & 830. & 731. & 788. & 889. & 884. & 808.6 & 861. & 1691. & 1714. & 1520. & 1642. & 801.1 & 830. & 711.9 & 781.0 \\
\hline & 12 & ${ }^{\circ} \mathrm{C}$ & ${ }^{\circ} \mathrm{C}$ & $1^{\circ} \mathrm{C}$ & $5^{\circ} \mathrm{C}$ & $9^{\circ} \mathrm{C}$ & $0^{\circ} \mathrm{C}$ & $5^{\circ} \mathrm{C}$ & $8^{\circ} \mathrm{C}$ & $9^{\circ} \mathrm{C}$ & $6^{\circ} \mathrm{C}$ & & $0^{\circ} \mathrm{C}$ & & & & & & & & ${ }^{\circ} \mathrm{C}$ \\
\hline & $\begin{array}{l}\text { Shand } \\
\text { wel-1 }\end{array}$ & $\begin{array}{l}103 . \\
2^{\circ} \mathrm{c}\end{array}$ & $\begin{array}{l}68.9 \\
{ }^{\circ} \mathrm{C}\end{array}$ & $\begin{array}{l}75 . \\
8^{\circ} \mathrm{c}\end{array}$ & $\begin{array}{l}82 . \\
6^{\circ} \mathrm{C}\end{array}$ & $\begin{array}{l}788 . \\
8^{\circ} \mathrm{c}\end{array}$ & $\begin{array}{l}884 . \\
6^{\circ} \mathrm{c}\end{array}$ & $\begin{array}{l}792 . \\
6^{\circ} \mathrm{c}\end{array}$ & $\begin{array}{l}822 . \\
0^{\circ} \mathrm{c}\end{array}$ & $\begin{array}{l}898 . \\
5^{\circ} \mathrm{C}\end{array}$ & $\begin{array}{l}915 . \\
7^{\circ} \mathrm{c}\end{array}$ & $\begin{array}{l}861.8 \\
{ }^{\circ} \mathrm{C} C\end{array}$ & $\begin{array}{l}892 . \\
0^{\circ} \mathrm{c}\end{array}$ & $\begin{array}{l}1691 . \\
0^{\circ} \mathrm{C}\end{array}$ & $\begin{array}{l}1741 . \\
1^{\circ} \mathrm{C}\end{array}$ & $\begin{array}{l}1593 . \\
8^{\circ} \mathrm{c}\end{array}$ & $\begin{array}{l}1675 . \\
3^{\circ} \mathrm{c}\end{array}$ & $\begin{array}{l}792.5 \\
{ }^{\circ} \mathrm{C} .\end{array}$ & $\begin{array}{l}825 . \\
4^{\circ} \mathrm{C}\end{array}$ & $\begin{array}{l}732.0 \\
{ }^{\circ} \mathrm{C}\end{array}$ & $\begin{array}{l}783.3 \\
{ }^{\circ} \mathrm{C}\end{array}$ \\
\hline & $\begin{array}{l}\text { Mean } \\
\text { (B) }\end{array}$ & $\begin{array}{l}80.6 \\
{ }^{8} \mathrm{C}\end{array}$ & $\begin{array}{l}71.8 \\
{ }^{\circ} \mathrm{C}\end{array}$ & $\begin{array}{l}60 . \\
5^{\circ} \mathrm{C}\end{array}$ & $\begin{array}{l}71 . \\
0^{\circ} \mathrm{C}\end{array}$ & $\begin{array}{l}822 . \\
0^{\circ} \mathrm{c}\end{array}$ & $\begin{array}{l}858 . \\
1^{\circ} \mathrm{c}\end{array}$ & $\begin{array}{l}761 . \\
1^{\circ} \mathrm{C}\end{array}$ & $\begin{array}{l}813 . \\
7^{\circ} \mathrm{c}\end{array}$ & $\begin{array}{l}906 . \\
5^{\circ} \mathrm{C}\end{array}$ & $\begin{array}{l}898 . \\
9^{\circ} \mathrm{c}\end{array}$ & $\begin{array}{l}838.8 \\
{ }^{\circ} \mathrm{C}\end{array}$ & $\begin{array}{l}881 . \\
4^{\circ} \mathrm{C}\end{array}$ & $\begin{array}{l}1704 . \\
2^{\circ} \mathrm{C}\end{array}$ & $\begin{array}{l}1747 . \\
7^{\circ} \mathrm{C}\end{array}$ & $\begin{array}{l}1561 . \\
8^{\circ} \mathrm{c}\end{array}$ & $\begin{array}{l}1671 . \\
2^{\circ} \mathrm{C}\end{array}$ & $\begin{array}{l}797.7 \\
{ }^{\circ} \mathrm{C} .\end{array}$ & $\begin{array}{l}848 . \\
8^{\circ} \mathrm{C}\end{array}$ & $\begin{array}{l}723.0 \\
{ }^{\circ} \mathrm{C}\end{array}$ & $\begin{array}{l}789.8 \\
{ }^{\circ} \mathrm{C} C\end{array}$ \\
\hline & $\begin{array}{l}\text { Giza- } \\
168 \\
\end{array}$ & $\begin{array}{l}53.7 \\
{ }^{\circ} \mathrm{C}\end{array}$ & $\begin{array}{l}84.0 \\
{ }^{\circ} \mathrm{C}\end{array}$ & $\begin{array}{l}79 . \\
3^{\circ} \mathrm{C} \\
\end{array}$ & $\begin{array}{l}72 . \\
3^{\circ} \mathrm{C} \\
\end{array}$ & $\begin{array}{l}844 . \\
7^{\circ} \mathrm{C}\end{array}$ & $\begin{array}{l}840 . \\
9^{\circ} \mathrm{C}\end{array}$ & $\begin{array}{l}875 . \\
7^{\circ} \mathrm{C}\end{array}$ & $\begin{array}{l}853 . \\
8^{\circ} \mathrm{C} \\
\end{array}$ & $\begin{array}{l}945 . \\
4^{\circ} \mathrm{c} \\
\end{array}$ & $\begin{array}{l}966 . \\
0^{\circ} \mathrm{C}\end{array}$ & $\begin{array}{l}981.6 \\
{ }^{\circ} \mathrm{C} C \\
\end{array}$ & $\begin{array}{l}964 . \\
3^{\circ} \mathrm{C} \\
\end{array}$ & $\begin{array}{l}1913 . \\
5^{\circ} \mathrm{C}\end{array}$ & $\begin{array}{l}1919 . \\
2^{\circ} \mathrm{C} \\
\end{array}$ & $\begin{array}{l}2089 . \\
1{ }^{\circ} \mathrm{C}\end{array}$ & $\begin{array}{l}1973 . \\
9^{\circ} \mathrm{C}\end{array}$ & $\begin{array}{l}968.1 \\
{ }^{\circ} \mathrm{C}\end{array}$ & $\begin{array}{l}953 . \\
2^{\circ} \mathrm{C} \\
\end{array}$ & $\begin{array}{l}1107 . \\
5^{\circ} \mathrm{c}\end{array}$ & $\begin{array}{l}1009 . \\
6^{\circ} \mathrm{C}\end{array}$ \\
\hline & Sids- 1 & $\begin{array}{l}64.5 \\
{ }^{6} \mathrm{c}\end{array}$ & $\begin{array}{l}73.9 \\
{ }^{\circ} \mathrm{C}\end{array}$ & 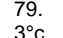 & $\begin{array}{l}72 . \\
6^{\circ} \mathrm{c}\end{array}$ & 853. & 828. & 889. & 857. & $\begin{array}{l}964 . \\
3^{\circ} \mathrm{c}\end{array}$ & 966. & $\begin{array}{l}1001 . \\
3^{\circ} \mathrm{c}\end{array}$ & 977. & 1966. & 1891. & $\begin{array}{l}2111 . \\
3^{\circ} \mathrm{c}\end{array}$ & 1990. & 1013. & $\begin{array}{l}925 . \\
9^{\circ} \mathrm{c}\end{array}$ & 1110. & $\begin{array}{l}1016 . \\
4^{\circ} \mathrm{c}\end{array}$ \\
\hline & Sids & 74.7 & 73.9 & 86. & 78. & 857. & 828. & 851. & 846. & 977. & 966. & 931.3 & 958. & 1890. & 1919. & 2089. & 1966. & 929.6 & 953. & 1157. & 1013. \\
\hline & & 64 & $\frac{{ }^{\circ} \mathrm{C}}{840}$ & $\frac{5{ }^{\circ} \mathrm{C}}{86}$ & $\frac{4^{\circ} \mathrm{C}}{78}$ & 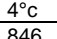 & $\frac{8^{\circ} \mathrm{C}}{855}$ & $\begin{array}{ll}9^{\circ} \mathrm{C} \\
917\end{array}$ & $\begin{array}{ll}0{ }^{\circ} \mathrm{C} \\
872\end{array}$ & $\frac{2^{\circ} \mathrm{C}}{9958}$ & $\frac{0^{\circ} \mathrm{C}}{984}$ & & $\frac{2^{\circ} \mathrm{C}}{974}$ & $\frac{9^{\circ} \mathrm{C}}{1189}$ & $\frac{2^{\circ} \mathrm{C}}{1946}$ & $\frac{1^{\circ}}{21}$ & $\frac{4^{\circ} \mathrm{C}}{2015}$ & $\begin{array}{llll}{ }^{\circ} \mathrm{C} \\
1021\end{array}$ & $\frac{2^{\circ} \mathrm{C}}{962}$ & & 37 \\
\hline & $\begin{array}{l}\text { Shand } \\
\text { wel-1 }\end{array}$ & $\begin{array}{l}64.5 \\
{ }^{\circ} \mathrm{C}\end{array}$ & $\begin{array}{l}84.0 \\
{ }^{\circ} \mathrm{C}\end{array}$ & $\begin{array}{l}86 . \\
5^{\circ} \mathrm{c}\end{array}$ & $\begin{array}{l}78 . \\
3^{\circ} \mathrm{C}\end{array}$ & $\begin{array}{l}846 . \\
0^{\circ} \mathrm{C}\end{array}$ & $\begin{array}{l}855 . \\
0^{\circ} \mathrm{c}\end{array}$ & $\begin{array}{l}917 . \\
1^{\circ} \mathrm{c}\end{array}$ & $\begin{array}{l}872 . \\
7^{\circ} \mathrm{C}\end{array}$ & $\begin{array}{l}958 . \\
2^{\circ} \mathrm{C}\end{array}$ & $\begin{array}{l}984 . \\
1^{\circ} \mathrm{c}\end{array}$ & $\begin{array}{l}{ }_{{ }^{\circ} \mathrm{C}} 91.6 \\
\mathrm{C}\end{array}$ & $\begin{array}{l}974 . \\
6^{\circ} \mathrm{c}\end{array}$ & 1989. & $\begin{array}{l}1946 . \\
1^{\circ} \mathrm{C}\end{array}$ & $\begin{array}{l}2111 . \\
3^{\circ} \mathrm{c}\end{array}$ & $\begin{array}{l}2015 . \\
6^{\circ} \mathrm{c}\end{array}$ & 1021. & 962. & $\begin{array}{l}1129 . \\
7^{\circ} \mathrm{c}\end{array}$ & $\begin{array}{l}1037 . \\
7^{\circ} \mathrm{c}\end{array}$ \\
\hline & $\begin{array}{l}\text { Mean } \\
\text { (B) }\end{array}$ & $\begin{array}{l}64.4 \\
{ }^{\circ} \mathrm{C}\end{array}$ & 79.0 & $\begin{array}{l}82 . \\
9^{\circ} \mathrm{C}\end{array}$ & $\begin{array}{l}75 . \\
4^{\circ} \mathrm{C}\end{array}$ & $\begin{array}{l}872 . \\
7^{\circ} \mathrm{c}\end{array}$ & $\begin{array}{l}838 . \\
4^{\circ} \mathrm{C}\end{array}$ & 883. & 864. & 974. & $\begin{array}{l}970 . \\
5^{\circ} \mathrm{C}\end{array}$ & $\begin{array}{l}974.0 \\
\end{array}$ & $\begin{array}{l}973 . \\
0^{\circ} \mathrm{c}\end{array}$ & 1940. & 1919. & 2100. & 1986. & 983.1 & 948. & 1126. & 1019. \\
\hline
\end{tabular}

Table (3): Days to emergence, heading, anthesis, maturity and grain filling period for cultivars and sowing dates.

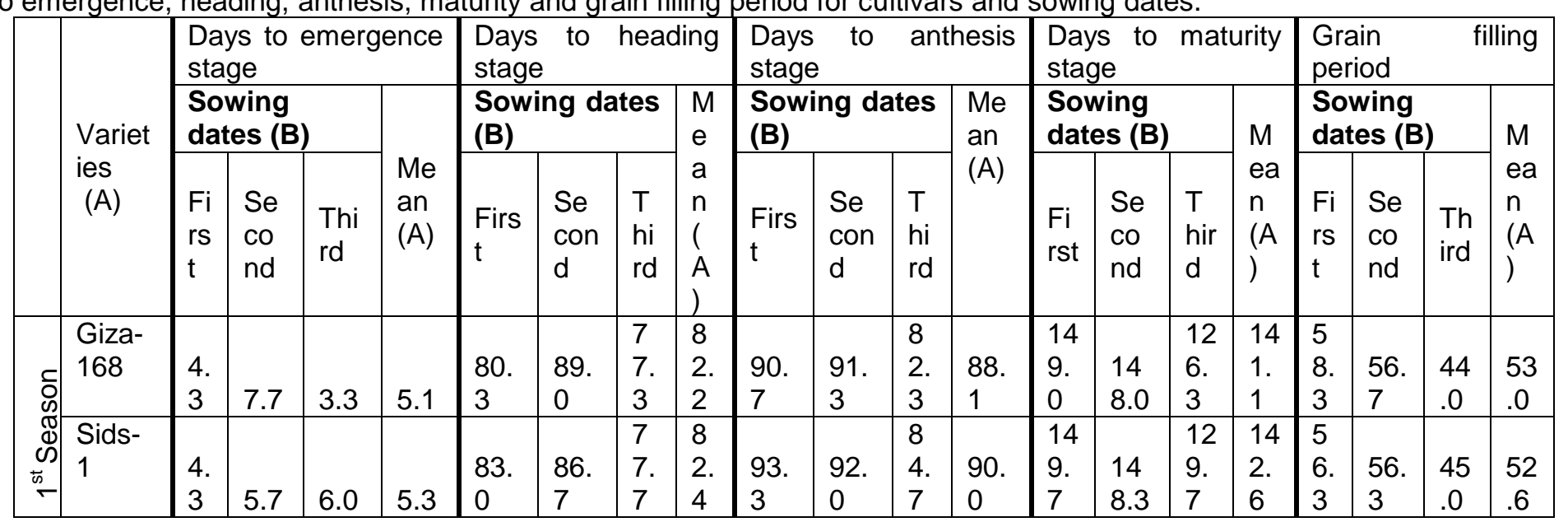




\begin{tabular}{|c|c|c|c|c|c|c|c|c|c|c|c|c|c|c|c|c|c|c|c|c|c|c|}
\hline & $\begin{array}{l}\text { Sids- } \\
12\end{array}$ & & \begin{tabular}{l|l}
6. & \\
3 & 7
\end{tabular} & 7.7 & 7.0 & 7.0 & $\begin{array}{l}80 . \\
3\end{array}$ & $\begin{array}{l}85 . \\
7\end{array}$ & $\begin{array}{l}7 \\
5 . \\
0\end{array}$ & $\begin{array}{l}8 \\
0 . \\
3\end{array}$ & $\begin{array}{l}89 . \\
0\end{array}$ & $\begin{array}{l}90 . \\
3\end{array}$ & $\begin{array}{l}8 \\
0 . \\
7\end{array}$ & $\begin{array}{l}86 . \\
7\end{array}$ & $\begin{array}{l}14 \\
7 . \\
7\end{array}$ & $\begin{array}{l}14 \\
6.0\end{array}$ & $\begin{array}{l}12 \\
6 . \\
3\end{array}$ & $\begin{array}{l}14 \\
0 . \\
0\end{array}$ & $\begin{array}{l}5 \\
8 . \\
7\end{array}$ & $\begin{array}{l}55 . \\
7\end{array}$ & $\begin{array}{l}45 \\
.7\end{array}$ & $\begin{array}{l}53 \\
.3\end{array}$ \\
\hline & $\begin{array}{l}\text { Shan } \\
\text { dwel- } \\
1\end{array}$ & & \begin{tabular}{l|l}
6. & \\
7 & 7
\end{tabular} & 7.3 & 8.0 & 7.3 & $\begin{array}{l}85 . \\
3\end{array}$ & $\begin{array}{l}89 . \\
7\end{array}$ & $\begin{array}{l}8 \\
0 . \\
0\end{array}$ & $\begin{array}{l}8 \\
5 . \\
0\end{array}$ & $\begin{array}{l}90 . \\
3\end{array}$ & $\begin{array}{l}93 . \\
7\end{array}$ & $\begin{array}{l}8 \\
5 . \\
3\end{array}$ & $\begin{array}{l}89 . \\
8\end{array}$ & $\begin{array}{l}14 \\
8 . \\
3\end{array}$ & $\begin{array}{l}14 \\
6.7\end{array}$ & $\begin{array}{l}12 \\
9 . \\
0\end{array}$ & $\begin{array}{l}14 \\
1 . \\
3\end{array}$ & $\begin{array}{l}5 \\
8 . \\
0\end{array}$ & $\begin{array}{l}53 . \\
0\end{array}$ & $\begin{array}{l}43 \\
.7\end{array}$ & $\begin{array}{l}51 \\
.6\end{array}$ \\
\hline & $\begin{array}{l}\text { Mean } \\
\text { (B) }\end{array}$ & & \begin{tabular}{l|l}
5. & \\
4 & 7
\end{tabular} & 7.1 & 6.1 & 6.2 & $\begin{array}{l}82 . \\
2\end{array}$ & $\begin{array}{l}87 . \\
8\end{array}$ & $\begin{array}{l}77 \\
7 . \\
5\end{array}$ & $\begin{array}{l}8 \\
2 . \\
5\end{array}$ & $\begin{array}{l}90 . \\
8\end{array}$ & $\begin{array}{l}91 . \\
8\end{array}$ & $\begin{array}{l}8 \\
3 . \\
3\end{array}$ & $\begin{array}{l}88 . \\
6\end{array}$ & $\begin{array}{l}14 \\
8 . \\
7\end{array}$ & $\begin{array}{l}14 \\
7.3\end{array}$ & $\begin{array}{l}12 \\
7 . \\
8\end{array}$ & $\begin{array}{l}14 \\
1 . \\
3\end{array}$ & $\begin{array}{l}5 \\
7 . \\
8\end{array}$ & $\begin{array}{l}55 . \\
4\end{array}$ & $\begin{array}{l}44 \\
.6\end{array}$ & $\begin{array}{l}52 \\
.6\end{array}$ \\
\hline & \begin{tabular}{l|l} 
L. & $A$ \\
S. & E \\
\cline { 2 - 3 } D. & $A$ \\
at & E \\
5 & \\
$\%$ &
\end{tabular} & & $\begin{array}{l}0.58 \\
0.61 \\
1.21\end{array}$ & & & & $\begin{array}{l}1.71 \\
1.52 \\
\text { NS }\end{array}$ & & & & \begin{tabular}{|l|}
1.25 \\
1.10 \\
NS \\
\end{tabular} & & & & $\begin{array}{l}\mathrm{NS} \\
0.8 \\
1.6\end{array}$ & & & & $\begin{array}{l}\text { NS } \\
1.4 \\
\text { NS }\end{array}$ & & & \\
\hline & $\begin{array}{l}\text { Giza- } \\
168\end{array}$ & & \begin{tabular}{l|l}
5. & \\
0 & 9
\end{tabular} & 9.0 & 9.0 & 7.7 & 91. & $\begin{array}{l}90 . \\
7\end{array}$ & $\begin{array}{l}8 \\
8 . \\
3\end{array}$ & $\begin{array}{l}9 \\
0 . \\
2\end{array}$ & $\begin{array}{l}100 \\
.3\end{array}$ & $\begin{array}{l}98 . \\
7\end{array}$ & $\begin{array}{l}9 \\
5 . \\
0\end{array}$ & $\begin{array}{l}98 . \\
0\end{array}$ & $\begin{array}{l}15 \\
9 . \\
7\end{array}$ & $\begin{array}{l}15 \\
1.3\end{array}$ & $\begin{array}{l}14 \\
5 . \\
3\end{array}$ & $\begin{array}{l}15 \\
2 . \\
1\end{array}$ & $\begin{array}{l}5 \\
9 . \\
3\end{array}$ & $\begin{array}{l}52 . \\
7\end{array}$ & $\begin{array}{l}50 \\
.3\end{array}$ & $\begin{array}{l}54 \\
.1\end{array}$ \\
\hline & $\begin{array}{l}\text { Sids- } \\
1\end{array}$ & & $\begin{array}{l}5 . \\
7\end{array}$ & 8.0 & 9.0 & 7.6 & $\begin{array}{l}89 . \\
0\end{array}$ & $\begin{array}{l}90 . \\
3\end{array}$ & $\begin{array}{l}8 \\
8 . \\
7\end{array}$ & $\begin{array}{l}8 \\
9 . \\
3\end{array}$ & $\begin{array}{l}100 \\
.7\end{array}$ & $\begin{array}{l}99 . \\
3\end{array}$ & $\begin{array}{l}9 \\
6 . \\
3\end{array}$ & $\begin{array}{l}98 . \\
8\end{array}$ & $\begin{array}{l}16 \\
2 . \\
3\end{array}$ & $\begin{array}{l}15 \\
0.0\end{array}$ & $\begin{array}{l}14 \\
5 . \\
7\end{array}$ & $\begin{array}{l}15 \\
2 . \\
7\end{array}$ & $\begin{array}{l}6 \\
1 . \\
7\end{array}$ & $\begin{array}{l}50 . \\
7\end{array}$ & $\begin{array}{l}49 \\
.3\end{array}$ & $\begin{array}{l}53 \\
.9\end{array}$ \\
\hline & $\begin{array}{l}\text { Sids- } \\
12\end{array}$ & & 7. & 7.7 & $\begin{array}{l}10 . \\
3\end{array}$ & 8.3 & $\begin{array}{l}90 . \\
7\end{array}$ & $\begin{array}{l}90 . \\
0\end{array}$ & $\begin{array}{l}8 \\
6 . \\
3\end{array}$ & $\begin{array}{l}8 \\
9 . \\
0\end{array}$ & $\begin{array}{l}102 \\
.0\end{array}$ & $\begin{array}{l}99 . \\
0\end{array}$ & $\begin{array}{l}9 \\
2 . \\
0\end{array}$ & $\begin{array}{l}97 . \\
7\end{array}$ & $\begin{array}{l}15 \\
9 . \\
0\end{array}$ & $\begin{array}{l}15 \\
1.0\end{array}$ & $\begin{array}{l}14 \\
5 . \\
0\end{array}$ & $\begin{array}{l}15 \\
1 . \\
7\end{array}$ & $\begin{array}{l}5 \\
7 . \\
0\end{array}$ & $\begin{array}{l}52 . \\
0\end{array}$ & $\begin{array}{l}53 \\
.0\end{array}$ & $\begin{array}{l}54 \\
.0\end{array}$ \\
\hline & $\begin{array}{l}\text { Shan } \\
\text { dwel- } \\
1\end{array}$ & & $\begin{array}{l}6 . \\
3\end{array}$ & 9.3 & 9.7 & 8.4 & $\begin{array}{l}93 . \\
7\end{array}$ & $\begin{array}{l}92 . \\
3\end{array}$ & $\begin{array}{l}9 \\
0 . \\
7\end{array}$ & $\begin{array}{l}9 \\
2 . \\
2\end{array}$ & $\begin{array}{l}102 \\
.7\end{array}$ & $\begin{array}{l}100 \\
.7\end{array}$ & $\begin{array}{l}9 \\
5 . \\
3\end{array}$ & $\begin{array}{l}99 . \\
6\end{array}$ & $\begin{array}{l}16 \\
2 . \\
7\end{array}$ & $\begin{array}{l}15 \\
2.3\end{array}$ & $\begin{array}{l}14 \\
6 . \\
3\end{array}$ & $\begin{array}{l}15 \\
3 . \\
8\end{array}$ & $\begin{array}{l}6 \\
0 . \\
0\end{array}$ & $\begin{array}{l}51 . \\
7\end{array}$ & $\begin{array}{l}51 \\
.0\end{array}$ & $\begin{array}{l}54 \\
.2\end{array}$ \\
\hline & $\begin{array}{l}\text { Mean } \\
\text { (B) }\end{array}$ & & \begin{tabular}{l|l}
6. & \\
0 & $\varepsilon$
\end{tabular} & 8.5 & 9.5 & 8.0 & $\begin{array}{l}91 . \\
3\end{array}$ & $\begin{array}{l}90 . \\
8\end{array}$ & $\begin{array}{l}8 \\
8 . \\
5\end{array}$ & $\begin{array}{l}9 \\
0 . \\
2\end{array}$ & $\begin{array}{l}101 \\
.4\end{array}$ & $\begin{array}{l}99 . \\
4\end{array}$ & $\begin{array}{l}9 \\
4 . \\
7\end{array}$ & $\begin{array}{l}98 . \\
5\end{array}$ & $\begin{array}{l}16 \\
0 . \\
9\end{array}$ & $\begin{array}{l}15 \\
1.2\end{array}$ & $\begin{array}{l}14 \\
5 . \\
6\end{array}$ & $\begin{array}{l}15 \\
2 . \\
6\end{array}$ & $\begin{array}{l}5 \\
9 . \\
5\end{array}$ & $\begin{array}{l}51 . \\
8\end{array}$ & $\begin{array}{c}50 \\
9\end{array}$ & $\begin{array}{l}54 \\
.1\end{array}$ \\
\hline & L. & & NS & & & & 1.11 & & & & \begin{tabular}{|l|}
0.97 \\
\end{tabular} & & & & NS & & & & NS & & & \\
\hline & & & 0.73 & & & & 0.6 & & & & 1.0 & & & & 1.5 & & & & 1.6 & & & \\
\hline 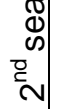 & $\begin{array}{l}\text { D. } \\
\text { at } \\
5\end{array}$ & & NS & & & & 1.24 & & & & \begin{tabular}{|l|}
2.07 \\
\end{tabular} & & & & NS & & & & 3.3 & & & \\
\hline
\end{tabular}




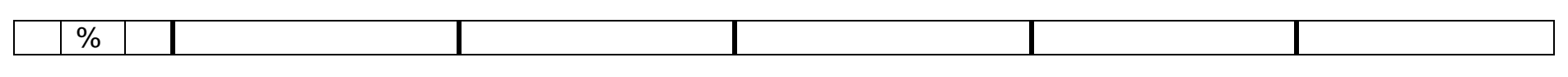

Table (4): Plant height, grain yield, H.I. and yield components of cultivars as affected by sowing dates.

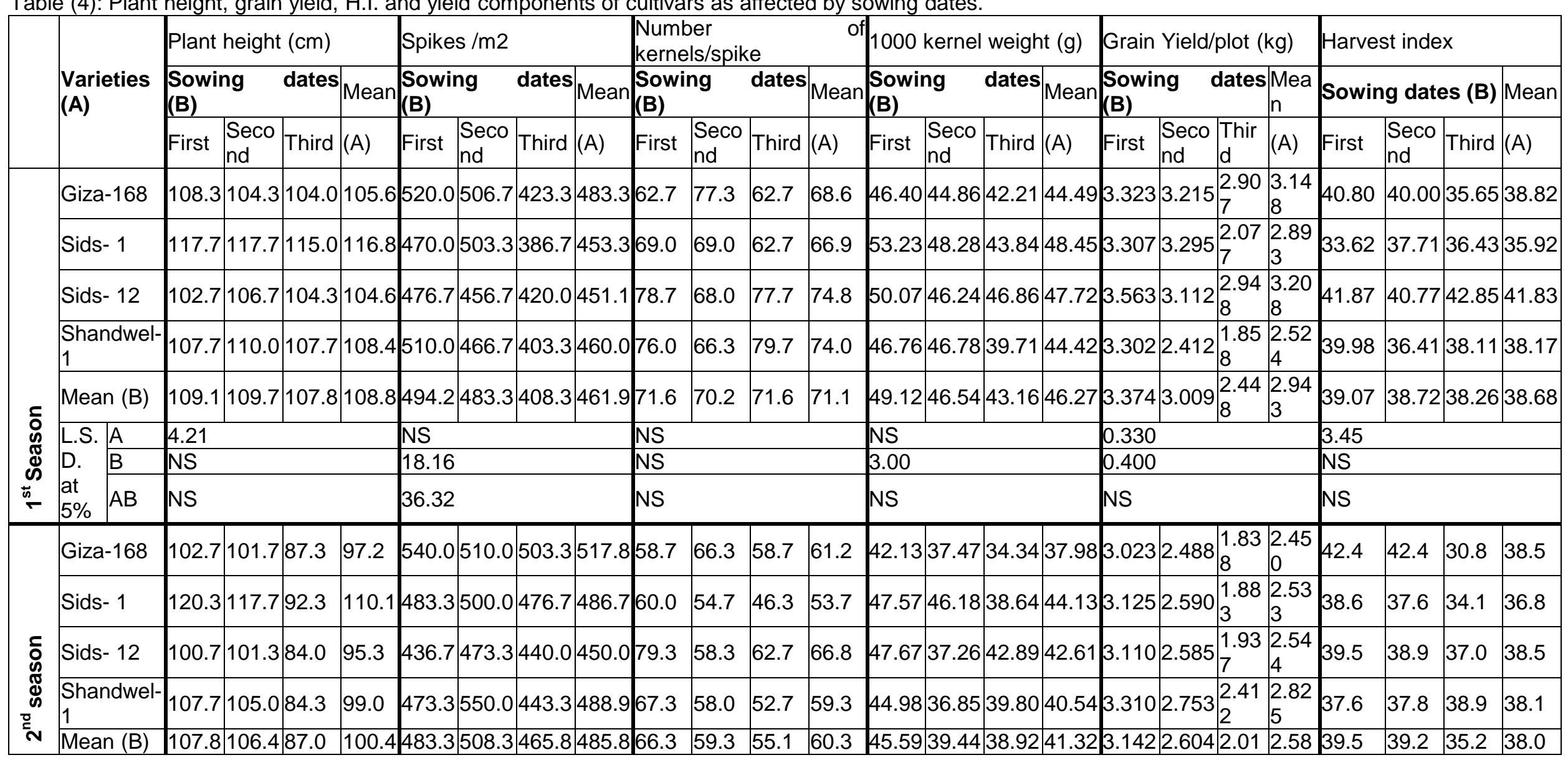


J. Plant Production, Mansoura Univ., Vol. 5 (2), February, 2014

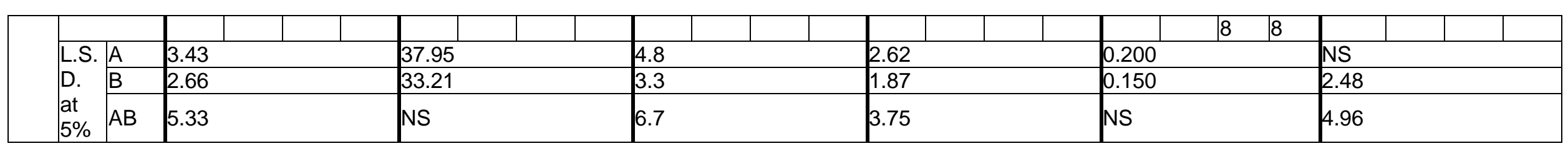



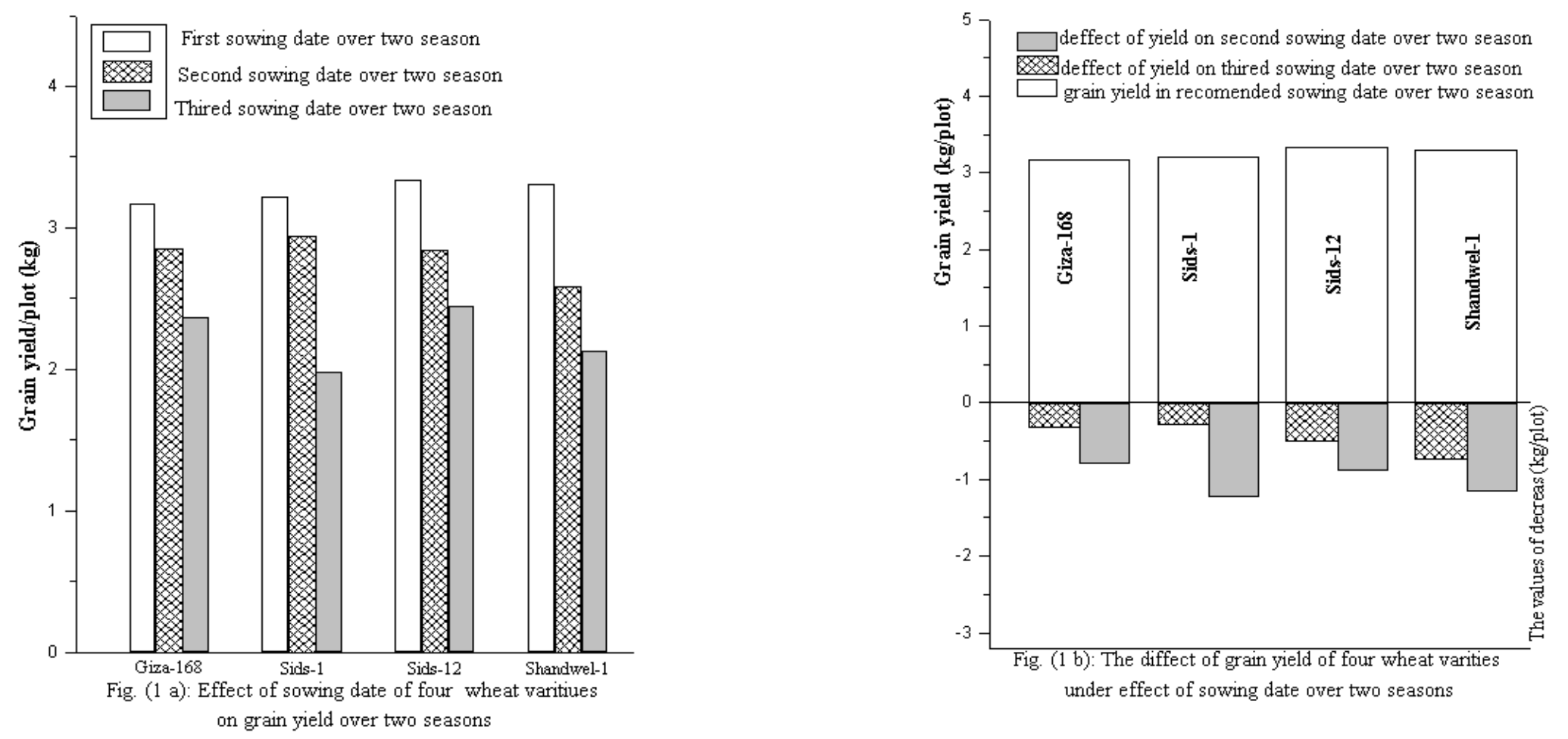

Figure, 1 (a\&b): Shows the effect of sowing date of four wheat varieties on grain yield (kg/plot) over two seasons and their defects. It is indicated that the highest production of grain yield was attained by Sids-12 flowed by Shandwel-1 and the lowest deficit was resulted from Giza-168 over two seasons that may be due to the high stability of this variety. 